\title{
Determination of $\beta^{S}$ haplotypes in patients with sickle-cell anemia in the state of Rio Grande do Norte, Brazil
}

\author{
Cynthia Hatsue Kitayama Cabral ${ }^{1}$, Édvis Santos Soares Serafim ${ }^{2}$, \\ Waleska Rayane Dantas Bezerra de Medeiros ${ }^{1}$, Thales Allyrio Araújo de Medeiros Fernandes ${ }^{3}$, \\ Elza Miyuki Kimura ${ }^{4}$, Fernando Ferreira Costa $^{5}$, Maria de Fátima Sonati ${ }^{4}$, \\ Ivanise Marina Moretti Rebecchi ${ }^{1}$ and Tereza Maria Dantas de Medeiros ${ }^{1}$ \\ ${ }^{1}$ Departamento de Análises Clínicas e Toxicológicas, Universidade Federal do Rio Grande do Norte, \\ Natal, RN, Brazil. \\ ${ }^{2}$ Hemocentro Dalton Barbosa Cunha, Natal, RN, Brazil. \\ ${ }^{3}$ Departamento de Ciências Biomédicas, Universidade do Estado do Rio Grande do Norte, \\ Mossoró, RN, Brazil. \\ ${ }^{4}$ Departamento de Patologia Clínica, Faculdade de Ciências Médicas, \\ Universidade Estadual de Campinas, Campinas, SP, Brazil. \\ ${ }^{5}$ Hemocentro, Universidade Estadual de Campinas, Campinas, SP, Brazil.
}

\begin{abstract}
$\beta^{s}$ haplotypes were studied in 47 non-related patients with sickle-cell anemia from the state of Rio Grande do Norte, Brazil. Molecular analysis was conducted by PCR/RFLP using restriction endonucleases Xmnl, HindIII, Hincll and Hinfl to analyze six polymorphic sites from the beta cluster. Twenty-seven patients (57.5\%) were identified with genotype CAR/CAR, 9 (19.1\%) CAR/BEN, 6 (12.8\%) CAR/CAM, 1 (2.1\%) BEN/BEN, 2 (4.3\%) CAR/Atp, 1 (2.1\%) BEN/Atp and $1(2.1 \%)$ with genotype Atp/Atp. The greater frequency of Cameroon haplotypes compared to other Brazilian states suggests the existence of a peculiarity of African origin in the state of Rio Grande do Norte.
\end{abstract}

Key words: haplotypes, $\beta$-globin, sickle-cell anemia, Brazilian population, $\mathrm{S}$ hemoglobin.

Received: November 26, 2010; Accepted: May 2, 2011.

Sickle-cell anemia, which results from the homozygosis of $\beta^{\mathrm{S}}$ allele [beta $6(\mathrm{~A} 3) \mathrm{Glu}>\mathrm{Val}$ ] of beta globin gene, is the most common and most serious form of sicklecell disease (Serjeant, 1997).

$\beta$-globin gene haplotype is characterized by the nonrandom association of cleavage sites recognized by restriction endonucleases (Steinberg et al., 1996). The main $\beta^{\mathrm{S}}$ haplotypes regularly found in patients with sickle-cell anemia, worldwide, are named according to the geographic region or ethnic group in which they were originally identified, i.e., Senegal (SEN), Benin (BEN), Bantu or Central African Republic (CAR), Cameroon (CAM) and Arab-Indian (ARAB), (Powars, 1991). Other less common haplotypes, known as atypical haplotypes (Atp), are generated by a number of genetic mechanisms (Zago et al., 2000).

The analysis of $\beta^{\mathrm{S}}$ haplotypes, besides being an important source for anthropological studies on the ethnic

Send correspondence to Tereza Maria Dantas de Medeiros. Departamento de Análises Clínicas e Toxicológicas, Universidade Federal do Rio Grande do Norte, Rua General Cordeiro de Farias $\mathrm{s} / \mathrm{n}, 1^{\circ}$ andar, 59010-180 Natal, RN, Brazil. E-mail: tdantas@ufrnet.br. composition of a population, contributes to a better understanding of the variation in clinical seriousness of sicklecell anemia, given that the different types of haplotypes contain a range of fetal hemoglobin concentrations that act as inhibitors of hemoglobin S polymer formation (Flint et al., 1998; Inati et al., 2003).

Senegal and Arab-Indian haplotypes, by producing the highest levels of fetal hemoglobin in the blood, are associated with less severe clinical evolution of sickle-cell anemia, with a lower occurrence of organic damage. As to the Benin and Cameroon haplotypes, the clinical picture is of intermediate severity. The Bantu or CAR haplotype is associated with greater clinical severity (Powars, 1991; Zago et al., 1992; Bortolini and Salzano, 1999).

In light of the absence of studies on haplotypes in the state of Rio Grande do Norte, the aim of the present investigation was to determine $\beta^{\mathrm{S}}$ haplotypes in a group of patients with sickle-cell anemia.

A total of 47 non-related individuals with sickle-cell anemia (25 males and 22 females) from the state of Rio Grande do Norte, aged between 10 months and 46 years (mean $16.1 \pm 10.4$ years), were analyzed. These patients 
were enrolled at the Hematology Ambulatory Care Facility of the Dalton Barbosa Cunha Hemocenter, Natal, RN, Brazil and the Oncology and Hematology Center of Mossoró, RN, Brazil. The research project was approved by the Research Ethics Committee of the Federal University of Rio Grande do Norte (CEP-UFRN, protocol number 090/07). All the patients or their legal guardians gave written informed-consent after being instructed on the aim of the study and the procedures involved.

Samples of venous blood were collected using EDTA as anticoagulant. The hemoglobin profile was determined by cellulose acetate electrophoresis at alkaline $\mathrm{pH}$ (Dacie and Lewis, 1995), and the presence of HbS confirmed by means of the solubility test (Magalhães and Arashiro, 1977). $\mathrm{HbA}_{2}$ was measured by elution from cellulose acetate strips following electrophoresis (Bezerra, 1984). The level of $\mathrm{HbA}_{2}$ was used to exclude the interation S- $\beta$ thalassemia. DNA was isolated from peripheral blood leukocytes using the illustra blood genomicPrep Mini Spin kit (GE Healthcare, Little Chalfont, Buckinghamshire, UK). $\beta^{S}$ halotypes were investigated by PCR/RFLP. PCR was performed using primers $\mathrm{H} 0, \mathrm{H} 1, \mathrm{H} 2, \mathrm{H} 3, \mathrm{H} 4, \mathrm{H} 5, \mathrm{H} 6, \mathrm{H} 7, \mathrm{H} 8$, H9 and H10 (Sutton et al., 1989) in a GeneAmp 9700 thermocycler (Applied Biosystem, Foster City, CA, USA). The analysis of polymorphic regions was by incubating PCR products with the restriction endonucleases $X m n \mathrm{I}$, HindIII, HincII and Hinfl, for $12 \mathrm{~h}$ at $37{ }^{\circ} \mathrm{C}$. Amplified products were visualized and polymorphic sites identified using $2 \%$ agarose gel electrophoresis, followed by ethidium bromide staining and photodocumentation (Sambrook et al., 1989). A 100 bp DNA Ladder (BioLabs) was applied in each gel electrophoresis as a standard molecular weight marker. Pre-determined homozygous and heterozygous patterns were used for each haplotype investigated.

The samples were marked by the presence $(+)$ or absence (-) of each of the 6 restriction sites analyzed in the beta-globin gene cluster $\left(X m n \mathrm{I} 5^{\prime} \gamma^{\mathrm{Go}}, \operatorname{Hind} \mathrm{III}\right.$ in $\gamma^{\mathrm{G}}$ and $\gamma^{\mathrm{A}}$, HincII in $3^{\prime} \psi \beta$ and $\psi \beta$, and Hinfl in $\left.5^{\prime} \beta\right)$. According to the combination of results, the five most common $\beta^{\mathrm{S}}$ haplotypes were defined as follows: CAR (- + - - - ), Benin (- - - $+-)$, Senegal $\left(+++_{-++}\right)$, Arab-Indian $(++-++-)$and Cameroon $(-++-++)$.

Of the 94 chromosomes analyzed, $71(75.5 \%)$ were characterized as CAR, $12(12.8 \%)$ as Benin, $6(6.4 \%)$ as Cameroon and $5(5.3 \%)$ as atypical haplotypes.

In relation to the combination of $\beta^{\mathrm{S}}$ haplotypes, 27 (57.5\%) patients carried the CAR/CAR genotype, 9 $(19.1 \%)$ the CAR/BEN, $6(12.8 \%)$ the CAR/CAM, 1 (2.1\%) the BEN/BEN, 2 (4.3\%) the CAR/Atp, 1 (2.1\%) the BEN/Atp, and 1 (2.1\%) the Atp/Atp.

The frequency of $\beta^{S}$ haplotypes varies according to origin. The African presence in Brazil began around 1550, as a replacement for native labor. The main ports of entry were Salvador, Recife and Rio de Janeiro. Individuals from
Nigeria, Daomé (present Day Benin) and the Ivory Coast were sent mainly to Bahia, whereas the Bantus, captured in the Congo, Angola and Mozambique, were sent to Pernambuco, Minas Gerais and Rio de Janeiro (Vicentino and Dorigo, 2002).

Since there were no ports or slave trade, the state of Rio Grande do Norte was not greatly influenced by African origin in its ethnic formation of the population. Moreover, unlike other regions, there was no economic activity requiring slave labor. As a result, only a small number of slaves, mainly from Pernambuco, were sent to this state (Cascudo, 1955).

Frequency distribution of $\beta^{\mathrm{S}}$ haplotypes in the patients included in this study and in others involving various Brazilian states, appear in Table 1. A general predominance of the CAR haplotype can be observed in the country (Zago et al., 1992; Gonçalves et al., 1994; Pante de Souza et al., 1998; Cardoso and Guerreiro, 2006; Bezerra et al., 2007; Silva et al., 2009). The Benin haplotype is present in all regions, with high frequency in Bahia (Costa et al., 1984; Gonçalves et al., 2003; Adorno et al., 2004) and Rio de Janeiro (Fleury, 2007).

The high frequency of CAR haplotype (75.5\%) found in the present study, followed by the Benin haplotype (12.8\%), was comparable to that obtained by Bezerra et al. (2007) in Pernambuco, the main source of slaves for Rio Grande do Norte. The frequency found for the Cameroon haplotype $(6.4 \%)$ was higher than that observed in other states such as Bahia, and even Pernambuco (Adorno et al., 2004, 2008; Cardoso and Guerreiro, 2006; Bezerra et al., 2007). Statistical analysis using the proportion comparison test showed a significant difference, except for the study conducted by Adorno et al. (2004) ( $\mathrm{p}=0.0943)$. No Senegal or Saudi Arabian haplotypes were identified in the study sample.

The record of a shipment of 2,400 African slaves from Andra, Benin, Warri (Niger Delta), Calabar and Cameroon to Pernambuco in 1638, during the Dutch occupation, confirms the entry of Africans from a region with high Cameroon haplotype frequency into northeastern Brazil (Alencastro, 2000). After 1845, with the rise in sugarcane production, slavery in Rio Grande do Norte increased, bolstered by the purchase of slaves from other states, such as Pernambuco and Maranhão (Medeiros, 1978). Hence, a possible explanation of the high frequency found in the present study, albeit also attributable to the small number of patients analyzed herein.

The present study constitutes the first attempt to investigate the frequency of $\beta^{\mathrm{S}}$ haplotypes in the population of the state of Rio Grande do Norte. The higher frequency of the Cameroon haplotype, compared to other Brazilian states, suggests the existence of a peculiarity of African origin. 
Table 1 - Summary of studies conducted in Brazil to investigate $\beta^{\mathrm{S}}$ haplotypes.

\begin{tabular}{|c|c|c|c|c|c|c|c|c|}
\hline \multirow[t]{2}{*}{ Author/year } & \multirow[t]{2}{*}{ Population } & \multirow[t]{2}{*}{$\mathrm{N}^{\mathrm{o}}$ of patients } & \multicolumn{6}{|c|}{ Haplotypes $\beta^{\mathrm{S}}(\%)$} \\
\hline & & & CAR & BEN & CAM & SEN & ARAB & Atp \\
\hline Costa et al. (1984) & São Paulo (SP) & 37 & 61.0 & 38.0 & - & - & - & 1.0 \\
\hline Zago et al. (1992) & São Paulo (SP) & 37 & 66.2 & 23.0 & - & 1.3 & - & 9.5 \\
\hline Gonçalves et al. (1994) & São Paulo (SP) & 74 & 62.2 & 33.8 & - & - & - & 4.0 \\
\hline Fleury (2007) & Rio de Janeiro (RJ) & 74 & 54.0 & 44.6 & - & 1.4 & - & - \\
\hline Costa et al. (1984) & Salvador (BA) & 36 & 49.0 & 51.0 & - & - & - & - \\
\hline Gonçalves et al. (2003) & Salvador (BA) & 80 & 48.1 & 45.6 & - & 0.7 & - & 5.6 \\
\hline Adorno et al. (2004) & Salvador (BA) & 80 & 46.2 & 48.8 & 1.9 & 0.6 & - & 0.6 \\
\hline Adorno et al. (2008) & Salvador (BA) & 125 & 41.6 & 55.2 & 1.2 & 0.4 & 0.4 & 1.2 \\
\hline Bezerra et al. (2007) & Recife (PE) & 74 & 81.1 & 14.2 & 0.8 & - & - & 3.9 \\
\hline This study & Natal (RN) & 47 & 75.5 & 12.8 & 6.4 & - & - & 5.3 \\
\hline Galiza Neto et al. (2005) & Fortaleza (CE) & 22 & 31.8 & 43.2 & - & 2.3 & - & - \\
\hline Silva et al. (2009) & Fortaleza (CE) & 34 & 66.2 & 22.0 & - & - & - & 11.8 \\
\hline Pante de Sousa et al. (1998) & Belém (PA) & 30 & 67.0 & 30.0 & - & 3.0 & - & - \\
\hline Cardoso and Guerreiro (2006) & Belém (PA) & 130 & 66.0 & 21.8 & 1.3 & 10.9 & - & - \\
\hline
\end{tabular}

\section{Acknowledgments}

This study was supported by the Conselho Nacional de Desenvolvimento Científico e Tecnológico (CNPq, grant n. 409766/2006-2) and the Fundação de Amparo à Pesquisa do Estado de São Paulo (FAPESP, grant n. 2008/57441-0).

\section{References}

Adorno EV, Zanette A, Lyra I, Souza CC, Santos LF, Menezes JF, Dupuit MF, Almeida MNT, Reis MG and Gonçalves MS (2004) The $\beta$-globin gene cluster haplotypes in sickle cell anemia patients from northeast Brazil: A clinical and molecular view. Hemoglobin 28:267-271.

Adorno EV, Zanette A, Lyra I, Seixas MO, Reis MG and Gonçalves MS (2008) Clinical and molecular characteristics of sickle cell anemia in northeast of Brazil. Genet Mol Biol 31:621-625.

Alencastro LF (2000) O Tratado dos Viventes: A Formação do Brasil no Atlântico Sul. Companhia das Letras, São Paulo, $525 \mathrm{pp}$.

Bezerra MAC, Santos MNN, Araújo AS, Gomes YM, Abath FGC and Bandeira MGC (2007) Molecular variations linked to the grouping of $\beta$ and $\alpha$-globin genes in neonatal patients with sickle cell disease in the state of Pernambuco, Brazil. Hemoglobin 31:1-6.

Bezerra TMM (1984) Quantificação de hemoglobina A 2 por eletroforese em acetato de celulose. Rev Bras Patol Clin 20:143-145.

Bortolini MC and Salzano FM (1999) $\beta^{\text {S }}$ haplotype diversity in afro-americans, Africans, and euro-asiatics - An attempt at a synthesis. Cienc Cult 51:175-180.

Cardoso GL and Guerreiro JF (2006) African gene flow to North Brazil as revealed by $\mathrm{HBB}^{*} \mathrm{~S}$ gene haplotype analysis. Am J Hum Biol 18:93-98.
Cascudo LC (1955) História do Rio Grande do Norte. Departamento de Imprensa Nacional, Rio de Janeiro, 524 pp.

Costa FF, Arruda VR, Gonçalves MS, Miranda SRP, Carvalho MH, Sonati MF, Saad SOT, Gesteira F, Fernandes D, Nascimento ML, et al. (1984) $\beta^{\mathrm{S}}$-Gene cluster haplotypes in sickle cell anemia patients from two regions of Brazil. Am J Hematol 46:96-97.

Dacie JV and Lewis SM (1995) Practical Haematology. Churchill Livingstone, Edinburgh, 608 pp.

Fleury MK (2007) Haplótipos do cluster da globina beta em pacientes com anemia falciforme no Rio de Janeiro: Aspectos clínicos e laboratoriais. Rev Bras Anál Clín 39:89-93.

Flint J, Harding RM, Boyce AJ and Clegg JB (1998) The population genetics of the haemoglobinopathies. Baillieres Clin Haematol 11:1-51.

Galiza Neto GC, Pitombeira MS, Vieira HF, Vieira MLC and Farias DAB (2005) Analysis of $\beta^{\mathrm{S}}$ globin gene haplotypes in Ceará, Brazil. J Bras Patol Med Lab 41:315-321.

Gonçalves MS, Nechtman JF, Figueiredo MS, Kerbauy J, Arruda VR, Sonati MF, Saad SOT, Costa FF and Stoming TA (1994) Sickle cell disease in a Brazilian population from São Paulo: A study of the $\beta^{\mathrm{S}}$ haplotypes. Hum Hered 44:322327.

Gonçalves MS, Bomfim GC, Maciel E, Cerqueira I, Lyra I, Zanette A, Bomfim G, Adorno EV, Albuquerque AL, Pontes A, et al. (2003) $\beta^{\mathrm{S}}$-haplotypes in sickle cell anemia patients from Salvador, Bahia, Northeastern Brazil. Braz J Med Biol Res 36:1283-1288.

Inati A, Taher A, Bou Alawi W, Koussa WS, Kaspar H, Shbaklo $\mathrm{H}$ and Zalloua PA (2003) $\beta$-globin gene cluster haplotypes and $\mathrm{HbF}$ levels are not the only modulators of sickle cell disease in Lebanon. Eur J Haematol 70:79-83.

Magalhães E and Arashiro DN (1977) Um método simples para visualização da hemoglobina $\mathrm{S}$ em teste de solubilidade. Rev Bras Patol Clin 13:133-134.

Medeiros T (1978) O negro na etnia do Rio Grande do Norte. Rev Inst Hist Geogr Rio Grande do Norte 70:95-97. 
Pante de Sousa G, Mousinho-Ribeiro RC, Santos EJM, Zago MA and Guerreiro JF (1998) Origin of the hemoglobin S gene in a northern Brazilian population: The combined effects of slave trade and internal migrations. Genet Mol Biol 21:427430.

Powars DR (1991) $\beta^{\mathrm{S}}$-gene-cluster haplotypes in sickle cell anemia. Hematol Oncol Clin North Am 5:475-493.

Sambrook J, Fritsch EF and Maniatis T (1989) Molecular Cloning: A Laboratory Manual. 2nd edition. Cold Spring Harbor Laboratory Press, New York, 1659 pp.

Serjeant GR (1997) Sickle-cell disease. Lancet 350:725-730.

Silva LB, Gonçalves RP and Rabenhorst SHB (2009) Analysis of sickle cell anemia haplotypes in Fortaleza reveals the ethnic origins of Ceará state population. J Bras Patol Med Lab 45:115-118.

Steinberg MH, Nagel RL, Lawrence C, Swaminathan V, Lu ZH, Plonczynski M and Harrell A (1996) $\beta$-globin gene haplotype in Hb SC disease. Am J Hematol 52:189-191.
Sutton M, Bouhassira EE and Nagel RL (1989) Polymerase chain reaction amplification applied to the determination of $\beta$-like globin gene cluster haplotypes. Am J Hematol 32:66-69.

Vicentino C and Dorigo G (2002). História Geral e do Brasil. Editora Scipione, São Paulo, 736 pp.

Zago MA, Figueiredo MS and Ogo SH (1992) Bantu $\beta^{\mathrm{S}}$ cluster haplotype predominates among brazilian blacks. Am J Phys Anthropol 88:295-298.

Zago MA, Silva-Júnior WA, Dalle B, Gualandro S, Hutz MH, Lapoumeroulie C, Tavella MH, Araújo AG, Krieger JE, Elion J, et al. (2000) Atypical $\beta^{\mathrm{S}}$ haplotypes are generated by diverse genetic mechanisms. Am J Hematol 63:79-84.

Associate Editor: Francisco Mauro Salzano

License information: This is an open-access article distributed under the terms of the Creative Commons Attribution License, which permits unrestricted use, distribution, and reproduction in any medium, provided the original work is properly cited. 